\title{
Public Accountability in Nigeria's Fourth Republic: an Overview
}

\author{
Uchem Raphael Onyebuchi \\ Department Of Political Science Nasarawa State University P.M.B 1022 Keffi-Nigeria West Africa
}

\begin{abstract}
The problem with democracy and good governance in Nigeria and the relationship between the people vis-à-vis public office holders is germane to this study. The paper submits that certain indices and provisions of public accountability in the breach than in observance. The research looks at public accountability as enshrined in the Nigerian Constitution is more honoured in Nigeria's Fourth Republic, the context of public accountability and the matters arising from it. The anti-corruption law and sustenance of democracy in Nigeria has also been discussed to clearly understand the rhetorics of Nigerian legal system in relation to affairs of practical governance. The paper concludes that for Nigeria to move forward, the leadership style must be revived to ensure a sustainable subsistence of affairs of state in the $21^{\text {st }}$ century.

Keywords: Accountability,Democracy, Fourth Republic,Leadreship,Sustainability.
\end{abstract}

\section{Introduction}

The emergence of western liberal democracy and the corresponding transmission of its waves across Third World countries of Africa, Asia, the Middle-East, the Caribbean and Latin America, respectively, has helped in widening the global socio-political and economic space around the world, so much so that the imperatives of self consciousness, awareness and determination have practically become the corner-stone of everyday life of the people. Only within such a framework are the defining conditions of democracy and democratization - contestation, participation, prudence, probity, public interests, etc. All of these are variables that allows for a workable social setting for overall interest of a nation-state. Olowu (1995) noted that it is within this context that African countries (Nigeria inclusive) are changing their strategies of socio-economic management from approaches dominated by private whims and caprices to those anchored on public interest. It is therefore not out of place for any government of the day to be held responsible and accountable for its actions or inactions with regards to certain pubic policy thrusts. Government and its agencies therefore could be seen as the 'peoples servant' and questions such as 'why' and 'how' certain things happen the way they do are brought to bear as very critical issues of collective national interest. The underlying assumption however is that government as a representative of the people becomes answerable to the same people it so represents in the affairs of state.

It also follows logically that matters of public interest are carefully harnessed and managed by those at the helms of affairs bearing in mind that democratic project and its survival is contingent on the level of policy consequences and how it impacts on the people at large. This paper attempts a plethora of literature on the subject matter of accountability, as well as the seeming relationship between accountability and transparency in Nigeria's Fourth Republic.

\section{Contextualizing Public Accountability}

The nexus of public accountability is a fluid concept defying unanimity in its actual meaning. Olowu (1995) agree that public accountability transcends individual interest and revolves around issues that can be considered as holistic in character and content. By any standard however, public accountability is synonymous to answerability for one's actions or behaviour. Conversely, in the business world, accountability involves the development of objective standard of evaluation to assist owners of such business outfits to evaluate the performance of duties by individuals and units. Within this framework, accountability can be seen from the perspective of reporting mechanism, responsibility as well as system of review, reward and sanctions. The above contentions are however ridiculous as they are economical. The phenomena is shrouded with shortcomings and limited in approach, and, hence, may not necessarily satisfy the aspirations of the teeming public (Nwabueze, 2010).

It is however interesting to note that in political science literature, there has been considerable debate dating back to Hobbes on whether the state as a sovereign should be accountable to anyone, since it was the sole guarantor of social peace, or that whether the state should be treated as a moral or responsible agent. Obviously, elements of both perspectives are found today in most national constitutions, but the preponderant view is that while the state must be self-accounting on the basis of the provisions of the constitution, the individuals who exercise state authority can be held accountable by actions of the state they represent (Abdulsalami, 1998; Wraith, 1963 and Okoye, 1989). 
Public Accountability In Nigeria's Fourth Republic: An Overview

However, Adakai (1998), Mckinney (1979) and Smith (1972) agree that public accountability represents the most desirable ideal in a democracy. It is linked to government obligation to some external forces or an acceptable standard or conduct. This is buttressed by Romzeek (1989) viz:

Accountability has two major meanings which overlap. First, there is the standard meaning common in democracies that those who exercise power, whether as government, as elected representatives or as appointed officials, are in a sense stewards and must be able to show that they have exercised their powers and discharged their duties properly. Secondly, accountability may refer to conformity between the values of a delegating body and the person or persons to whom powers and responsibilities are delegated (1989:3).

The foregoing excerpts looks at public accountability from the realm of politics which is the main thrust of this paper. However, at various levels of intellectual discourses, accountability does not only limit itself to the political, it also concerns itself with the bureaucratic, legal, professional and financial accountabilities, respectively (Elema, 2010; HRW, 2002).

\section{Public Accountability and Nigeria's Fourth Republic: Matters Arising}

The exemplifying circumstances surrounding the Nigeria's Fourth Republic under the erstwhile Obasanjo's administration appears to have honoured the ethics of republic accountability more in the breach than in observance (Diamond, 2004; D'Donnel 2003; Lawson, 2002). It is interesting to note that upon his assumption of office in May, 1999, a 20-man Presidential Advisory Committee was set up to chart a new political direction for the already comatose Nigerian state system. However, after the necessary first step in office as democratically elected president, Nigerians to their greatest chagrin, discovered that things were going to change from better to worse (Efenji, 2010, Nwadialor, 2009). Consequently, the rot in the system is evident in virtually every facet of the Nigerian economy either at the level of the political, economic, environmental, security, social and even international dimensions (Ezugwu, 1999, Davis, 1995; Chinweizu, 1978).

In the first instance, Abada (2004) wrote that the Obasanjo regime has been faced with a retinue of problems ranging from inter-communal crises, sharia saga, executive legislative fracas; issues on the NigerDelta imbroglio, human right violation, electoral reform Acts, among others. The multiplier effects of these petty oddities had propelled unimaginary dearth of peace and tranquility in the Nigerian state and the people had known no peace to date. Scholars in the social sciences had attempted to explain this scenario via the age-long wrath that has been bottled over time without complain for fear of the military's high-handedness. These have been found to be the aftermath of long-term hatred, suspicion and fear of political and economic dominations in the Nigerian state system (Livingstone, 1964, Ikejiari, 1995; Werlin 1972).

Similarly, Ekpo (1995) noted that the off-short of previous regime types from Nigeria's political history merely pre-cludes what was been expected in the near future. It is conventional however to note that neither the first Nigeria's Republic nor the second, or Third (though abortive in outlook), had very little dissimilarities in both character and content (Benson, 1978; Leys, 1965). Of particular importance is the nature of Nigerian politics which characteristically expresses itself in wanton negation and violation of human rights, free extra-judicial killings and assassination, prolong detention of purported criminals without trial, godfatherism, political thuggery, among others. All of these have largely deified successive administrations in Nigeria in no small way, hence, the down-trodden masses are largely left in the cold helplessly.

Abada (2004) noted however that the singular tendency of the Obasanjo administration to tinker with the peoples mandate through subvertion of the 2001 Electoral Act is the height of irresponsibility and accountability or the lack of it. Conversely, the controversial Electoral Act has posed a very big question mark to the presumed Obasanjo's public accountability. The controversial clause infiltrated into the Act which was however bluntly denied by both the president and members of Nigeria's parliament is a hoax and fundamentally, a monumental set-lack on Nigeria's path to nationhood. Elaigwu (2002) succinctly opined that:

Unlike politicians in the western world, our politicians lack adequate capabilities. They find it difficult to apologize to the public when they make mistakes or commit political blunders in decision making. Otherwise, how can one explain the multi-dimensional trading of blames on the fraudulent insertion of Section 80 (1) of the Electoral Law 2001? No one has bothered to apologize to Nigerians. Yet none of the actors can claim ignorance of the issue before and during the process of making the law (2002:13).

The aforementioned is to say the least. Mention would also be made of the ensuing sour relationship between the Executive and the Legislature either at the grassroot, state or central levels, respectively. Thus President Obasanjo's overbearing attitude and character manifested itself right from the on-set with the election of the leadership of the two chambers of the National Assembly. The same has been severally accused of 'meddling' in the internal of the National Assembly with impunity. This has actually destabilized the upper chambers while the House of Representative has been at war with the executive arm. However, Elaigwu (2002) noted that Obasanjo may have borrowed a leaf of his character traits from his military background which accounts to why he is resolute in most of his doing without recourse to public outcry. To Elaigwu:

Occasionally, the executive behaved as if it did not understand the complimentary role of the legislature. Thus when Obasanjo told the nations on television and radio that if the legislature was not ready to 
Public Accountability In Nigeria's Fourth Republic: An Overview

work with him, he was ready to do it alone. He was certainly oblivious of the fact that he could not do so. It was surprising that he was taken up in the press. While the initial display of Messianic arrogance is fading gradually, it seems that the President's military background is not allowing for the erosion of residual militarism in the polity (2002:19).

The foregoing is a rip-off of all acceptable behavioural standards which is also detrimental to sociopolitical growth, sustenance and process. It is rather a show-off of political rigmarolling and summersault which barely leaves nothing in its trail of wanton destruction. It is a phenomenon akin to a systemic failure that may only need the intervention of nature to be able to put things in their right places, so that Nigeria can move forward.

\section{Public Accountability, Anti-Corruption Law And Sustenance Of Nigeria's Fourth Republic}

The emergence of Chief Olusegun Obasanjo as Nigeria's President in May, 1999 brought with it laws that are supposed to move the ship of state forward. It was hoped that the new law would mark a turning point all the major aspects of the Nigerian lives either economically, socially, culturally and politically (FRCN, 2004). It is also particularly imperative to note that the evil of corruption has eaten deep into the moral fabric of the Nigerian society and has adversely affected all and sundry including the rulers and the ruled. Corruption and its stigma wears an ugly looks and, hence, manifests in virtually all aspects of Nigeria's national life. To Obasanjo (2000) opine that:

Corruption was identified as number one enemy of development and progress. Combating corruption was easily the number one priority action for our administration... corruption is a cankerworm that has eaten into the fabric of our society at every level. It has caused decay and dereliction within the infrastructure of government and the society in physical, social and human terms. Corruption has been successive governments since the First Republic. Every coup then has been in the name of stamping out the disease called corruption. Unfortunately, the cure often turned out to be worse than the disease... Nigeria's external image took a serious bashing, as our beloved country began to feature on top of every corruption index (2000:4).

It appears from the above excerpts that the malaise of corruption affects every leadership and followership, as demonstrated by Mr. President. The phases of corruption in Nigeria therefore run parallel to accountability, transparency and good governance. The models of corruption in Nigeria including giving and accepting gratification, concealing offences relating to corruption, fraudulent acquisition or receipt of property, making false or misleading statements, insincerity in advice with the aim of gaining undue advantage, outright looting of public thrusts or treasury, neglect of duties, etc, have largely barred the Nigeria's road to peace, progress ad stability alike (Bayley, 1966; Achebe, 1983; Diya, 1994).

By any standard, however, the spate of corruption and arbitrary display of affluence in Nigeria has shown a country where public issues as critical as corruption and/or accountability as being treated with levity even though the laws are there as prescribed by the constitution to punish offenders. For example, the law prescribes various forms of punishment for culprits found guilty of corruption. Section 9(1) stipulates that:

Any person who corruptly gives, offers, or procures any property or benefit of any kind to, on or for a public officer or to, on or for any other person; or promises to give, confers, procure or attempts to procure any property or benefit of any kind to, on or for any public officer or any other person... is guilty of an offence and he or she is liable to prison terms spanning not less than 7 years (my emphasis added).

It is in line with the above that government had set up the Economic and Financial Crimes Commission (EFCC) and the Independent Corrupt Practices and other related offences Commission (ICPC) to checkmate corrupt cases. It appears also that the question of public accountability has defied acceptable standards and hence, several retinue of corruption has been reported in the Nigerian State of late. It also looks like there has been an astronomical and progressive crescendo in terms of movement of corruption on the socio-political scalar-chain of the Nigerian polity. Habib (2000) was stunned with the level of graft in Nigeria where he remarked that:

There can be white washing of the stinking dirt of financial recklessness that has been swept out if the bowels of claim and payment vouchers in the National Assembly... the public office holders have consistently parted company with their oath of office with regard to public funds. Driven by greed, they made deep treasure excavations from the public purse (2000:16).

Within the context of the above arguments, it can be deduced that the Nigeria's Fourth Republic which laid the foundation for a change of attitude of the nation's polity was not in itself so transformed. It is painful that the ruling Peoples Democratic Party (PDP) and its flag bearers have decided to be inconsistently consistent in their profile of promises and blue-paper democratic dividends. The Nigerian leadership cannot be permitted to confuse public office for public looting as has been exemplified from the beginning of the so-called "genuine democracy" in 1999. Public accountability or the lack of it has been obvious and cuts across all facets of the nation's political system. It covers both the power sector, telecommunications, aviation, INEC, to mention but a few. In the power sector, for example, sources rightly pointed out that: 
... with Obasanjo and Imoke in control, the National Integrated Power project contracts were handed over to their friends and associates like candies at children's party. Over 300 contracts were approved, while 340 payments were made (Olutu, 2008:66).

Similarly, it is difficult to define public accountability on the premise of having those who are supposed to be custodians of the peoples mandate in Nigeria. In another very palpable development over one of the very may public melodrama, Abdullahi (2008) wrote that:

Nigerians were stunned to learn at the public hearing that despite the payment of about \$257 billion (an equivalent of \& 2.10 billion) to contractors, work has not commenced on most of the project sites. Contractors and supposed supervisors of different projects openly contradicted each other on the existence of certain projects, the contract sum and the extent of work carried out by site contractors (2008:67).

The foregoing sums up the public insinuations that Nigeria is such a place that leadership at least, at all levels, may necessarily be held accountable for the loopholes they commit. It is inexhaustive to discuss the vagaries of corruption and the lack of public accountability in the Nigerian system. This is because any attempt to do this will naturally amount to waste of intellectual energy. Consequently, conscious efforts must be made to address problems of greed and gross abuse of public thrusts. This will no doubt, engender the culture of sociopolitical development, progress and stability, so Nigeria can be proud owners of collective intergrity, justice and transparency in every angle of our national lives.

\section{Conclusion}

The study looks at public accountability in Nigeria's Fourth Republic with a view to proffering viable solutions for the corporate existence of Nigeria at large. The paper submits that the crux of democratic survival and sustenance of any society is contingent on the forward and backward linkages in terms of management of affairs of state. The standard measurement for success therefore requires group interest and the consideration that no single individual in Nigeria is more than the entire people of Nigeria. However, the import of this discourse is the closer experimentation of the relationship that is supposed to exist between the people and those at the helms of government. The Nigerian leadership should therefore be representative and answerable enough to be able to give account of their stewardship to the people. The blunt politics of deceit as orchestrated by certain people especially at the presidency in recent times, thereby creating a leadership lacuna for several months to date does not show concern for public accountability.

The missing link generated between Nigerian legislators and their constituencies is a negation of public accountability. Refusal to sign into laws Public Bills in public interest is a violation of peoples rights and privileges. Selective justices as exemplified by the PDP led government in the present Nigeria dehumanizes all globally acceptable best practices and should not be allowed to subsist. Nigeria at this critical period requires true democracy and effective leadership capable of transforming the nation to eldorado. Any attitude by persons or group of persons to undermine this singular collective interest may only frustrate the intents and aspirations of the people thereby leading the entire nation to a waterloo; a condition detrimental to our corporate survival and realization of established hopes and aspirations in all its ramifications.

\section{References}

[1] Abada, I. M. 2004. An Assessment of Public Accountability in Nigeria Under Obasanjo's Regime. Enugu: Vantage Pub.

[2] Abdulsalami, A. 1998. Accountability and Policy Making in the Local Government System. Ibadan: Sam Bookman Pub.

[3] Achebe, C. 1983. The Trouble With Nigeria. Enugu: Fourth Dimensions Pub.

[4] Adakai, E. A. 1998. Towards Effective Financial Accountability in Local Government System in Nigeria. Jos: Matchers Pub.

[5] Akpan, N. U. 1982. Public Administration in Nigeria. Lagos: Longman.

[6] Bayley, H. D. 1966. The Efferent of Corruption in a Developing Nation. Western Political quarterly, Vol. 19 (4).

[7] BBC World Service "The President Speaks" Voices in the Dark, January.

[8] Benson, C. 1978. Political Corruption and Accountability in America. Lexington: Lexington Books.

[9] Diamond, L. 2004. Building a System of Comprehensive Accountability to Control Corruption in Agbaje, A. (ed) Nigeria's Struggle for Democracy and Good Governance. Ibadan: Ibadan University Press.

Diya, O. 1994. Corruption and the Military. Tell Magazine, August.

[11] Chinweizu, R. 1978. The West and the Rest of Us. London: Nok Pub.

[12] Davies, A. E. 1995. Executive Legislative Relations and Democratization During the Transition Programme. Ibadan: University of Ibadan Press.

[13] Efenji, E. 2010. Where is Nigeria's President? AIT News Flash, January.

[14] Egwu, E. U. 1995. The Psychodynamics of Corruption in Nigeria. Enugu: Acena Pub.

[15] Elema, D. 2010. This Vacuum that is Created: Who is to Blame? The Nation, January.

[16] Ezugwu, J. S. 1999. Corruption and Economic Sabotage, Daily times, March.

[17] Federal Radio Corporation of Nigeria 2004.

[18] Human Rights Watch, 2002.

[19] Ikejiani-Clark, M. 1995. Corruption in Nigeria. Enugu. Acana Publishers.

[20] Lawson, C. H. 2002. Building the Fourth Estate: Democratization and the Rise of a Free Press in Mexico. Berkeley: University of California Press.

Leys, C. 1965. What is the Problem About Corruption. Journal of Modern African Studies, Vol. 3 (2).

[22] Livingstone, J. C. and Thompson, R. G. 1964. The Concept of the Governed. New York: Macmillan.

[23] McKinney, J. B. and Howard, L. C. 1979. Public Administration: Balancing Power and Needs. Illinois: Moore Pub. 
[24] Nwabueze, N. 2010. In Mr. President's Absence, Who is Next? AIT Political Ringtone: Matters Arising, February.

[25] Nwadialo, M. 2009. The Executive and Accountability in Nigeria's Chequered Democracy. The Nation, December.

[26] O'Donnell, G. 2003. Horizontal Accountability in New Democracies. London: Oxford University Press.

[27] Okoye, I. 1989. Corruption and Politics in Nigeria: A Case Study of the Eastern Central State. Nsukka: Kens Pub.

[28] Putnam, R. D. 1993. Making Democracy Work: Civic Traditions in Modern Italy. Princeton: Princeton University Press.

[29] Romzeek, D. 1987. Accountability in the Public Sector: Lessons from the Challenger Tragedy. Public Administration Review, Vol. 47(3).

[30] Smith, B. L. and Hague, D. C. 1972. The Dilemma of Accountability in Modern Government: Independence Versus Control. New York: St. Martins Press.

[31] Wraith, R. and Simkins, E. 1963. Corruption in Developing Countries. London: George Allen and Unwin.

[32] Werlin, H. H. 1972. The Roots of Corruption - The Ghanaian Enquiry Journal of Modern African Studies 10 (2). 